Vol. 16 (2007): 115-123

\title{
Genetic analysis of clinical mastitis during different risk periods in Finnish Ayrshire
}

Enyew Negussie, Ismo Strandén, Esa A. Mäntysaari

MTT Agrifood Research Finland, Biotechnology and Food Research, Biometrical Genetics, FI-31600 Jokioinen, Finland, e-mail: enyew.negussie@mtt.fi

\begin{abstract}
Clinical mastitis (CM) records from first-lactation Finnish Ayrshire were analysed by linear and threshold models to assess the effects trait definition on estimates of genetic parameters and sire evaluation. The studied CM traits were defined by dividing lactation into six lactation stages (risk periods) by days (d) after calving: CM1 (-7 to $150 \mathrm{~d}$ ), CM2 (-30 to $30 \mathrm{~d}$ ), CM3 (-30 to $150 \mathrm{~d}$ ), CM4 (31 to $150 \mathrm{~d}$ ), CM5 (150 to $300 \mathrm{~d})$, CM6 (-30 to $300 \mathrm{~d})$. In addition, two data sets were prepared to assess the effect of excluding (Data I) or including (Data II) records of culled cows on estimates of genetic parameters. Sire variances and heritabilities were larger using Data II. When data from longer intervals was used heritabilities of CM were slightly higher than shorter intervals indicating that longer intervals tend to obscure genetic variation between animals. Of all CM traits, heritability of liability to CM with threshold-liability model was highest for CM2 $\left(\mathrm{h}^{2}=0.083\right)$ implying that most of the genetic information on CM is in early lactation. In sire evaluation, a multitrait index calculated by combining CM2, CM4 and CM5 had the highest correlation with all other univariate $\mathrm{CM}$ trait evaluations. This and the magnitude (less than 1.0) of genetic correlations between CM traits suggest that a multitrait model considering CM from the different risk periods would be appropriate for CM sire evaluation.
\end{abstract}

Key-words: Dairy cattle, genetic parameters, clinical mastitis, Bayesian analysis

\section{Introduction}

Mastitis is one of the most common and costly diseases in dairy cattle. It is also the leading reason for premature disposal of Finnish Ayrshire cows.
Apart from its effect on milk production, the high cost of mastitis is due to the cost of replacement heifers for culled cows. Besides, culled cows have incomplete lactation records in other words missing data (Little and Rubin 1987, Im et al. 1989). Including or excluding records of culled cows in 


\section{AGRICULTURAL AND FOOD SCIENCE}

Negussie, E. et al. Genetic analysis of clinical mastitis

statistical analysis may cause data sampling biases. Moreover, the use of information about culled cows affects variance component estimates.

So far there are only few studies that considered CM during the different sampling periods and evaluated the effect of information from culled cows. From Swedish data, Koenen et al. (1994) reported significantly higher heritability estimates for mastitis when information on culled cows was included in the evaluation. Heringstad et al. (2001a) divided first lactation from 15 days before calving to 210 days into 8 periods to assess the effect of sampling period on the heritability and genetic associations between CM traits using a linear sire model. They found that heritability increased slightly with the increase in the sampling interval and the longest period analysed gave the highest heritability estimate. However, the sampling period covering 15 days before first calving to 30 days after calving captured a large part of the genetic variation.

Using Bayesian threshold models Chang et al. (2004) analysed the effect of different CM trait definitions on estimates of genetic parameters and sire evaluations. The estimates of heritability of liability to $\mathrm{CM}$ ranged from 0.06 to 0.14 , depending on the model and stage of lactation. In multi-period models genetic correlations between periods were positive and ranged from 0.13 to 0.55 . For Finnish Ayrshire, Pösö and Mäntysaari (1996) and Negussie et al. (2006) used linear sire models to analyse $\mathrm{CM}$ defined over single interval going from 7 days before calving to 150 days after calving. However, clinical mastitis occurs unevenly during the course of lactation (Koivula et al. 2005), and the use of single and relatively longer intervals may result in loss of information. Thus a clear understanding of the genetic variation associated with $\mathrm{CM}$ traits defined over the different risk periods is essential in deciding about the best measure of $\mathrm{CM}$ when estimating variance components or predicting breeding values. The objectives of this study were first: to assess the effects of CM trait definition on estimates of covariance components and associated genetic parameters using linear and threshold models; second: to evaluate the effects of information about culled cows on estimates of covariance components and associated parameters and third: to assess the genetic association between different $\mathrm{CM}$ traits and its effect on sire evaluation using linear sire models.

\section{Material and Methods}

The data came from more than 112000 first lactation Finnish Ayrshire cows calving from 1992 to 2002. The cows were selected from herds that were actively participating in the health-recording scheme. Only first crop daughters (i.e. difference between the birth year of a daughter and that of her sire was less than 6 years) were included. Additional requirements were: a sire should have at least 20 daughters in the analysis, and the age at first calving should be between 23 and 30 months. The pedigree file had 1226 males, of which 979 sires had daughters in the data.

The whole first lactation was divided into six risk periods by days (d) after calving as follows: CM1 (-7 to $150 \mathrm{~d}), \mathrm{CM} 2$ (-30 to $30 \mathrm{~d}), \mathrm{CM} 3$ (-30 to $150 \mathrm{~d}$ ), CM4 (31 to $150 \mathrm{~d}$ ), CM5 (150 to 300 d), CM6 (-30 to $300 \mathrm{~d})$. These intervals were selected with the aim to assess the genetic variation associated with the different risk periods and also with alternative definitions of CM for use in the genetic evaluation of mastitis. In addition, two data sets were prepared in order to assess the effects of records from cows that had been culled from the herd before the end of the risk period. In the first data (Data I), records of cows culled before the end of the risk period were not included. Whereas in the second data (Data II), records of cows culled before the end of the risk period were included if the cow had been culled for mastitis reasons. Within each interval, for each cow CM was defined as a binary trait with " 0 " or " 1 " based on whether or not a cow had at least one veterinary treatment or was culled from the herd because of mastitis. Descriptions of the data used are in Table 1. 
Vol. 16 (2007): 115-123

Table 1. Number of records (No.) and percentage of cows with clinical mastitis (CM-\%) during the different risk periods in data sets without (Data I) ${ }^{1}$ and with (Data II $)^{2}$ information on culled cows.

\begin{tabular}{|c|c|c|c|c|}
\hline \multirow{2}{*}{$\begin{array}{l}\text { Traits } \\
\text { (Days after calving) }\end{array}$} & \multicolumn{2}{|c|}{${\text { Data }{ }^{1}}^{1}$} & \multicolumn{2}{|c|}{ Data II $^{2}$} \\
\hline & No. & CM-\% & No. & CM- $\%$ \\
\hline CM1 (-7-150) & 110722 & 8.41 & 111256 & 8.89 \\
\hline CM2 (-30-30) & 112329 & 6.28 & 112554 & 6.48 \\
\hline CM3 (-30-150) & 110667 & 8.50 & 111256 & 9.03 \\
\hline CM4 (31-150) & 110736 & 2.50 & 111270 & 2.98 \\
\hline CM5 (151-300) & 104955 & 2.50 & 106909 & 4.36 \\
\hline CM6 (-30-300) & 103075 & 10.5 & 105597 & 12.88 \\
\hline
\end{tabular}

${ }^{1}$ Data I: Records of cows culled before the end of the risk period were not included.

${ }^{2}$ Data II: Records of cows culled due to mastitis before the end of the risk period were included.

\section{Statistical model}

Threshold and linear sire models were used for estimation of covariance components and associated genetic parameters. Heritabilities for the six CM traits were estimated with the univariate analyses while genetic correlations were estimated with bivariate and trivariate analyses involving two or three traits at a time, respectively.

\section{Bayesian analysis}

Threshold-liability model (Gianola 1982) was used for the analysis of CM traits. For the binary variable $\mathrm{CM}$, the model uses the threshold concept (Dempster and Lerner 1950, Falconer 1981), where an underlying continuous variable, liability $(\lambda)$ is assumed. Thus, the observed binary variable takes a value of 1 if $\lambda$ is larger than a fixed threshold and 0 otherwise. With the binary data, since the threshold and the residual variance are not identifiable these parameters were set to 0 and 1 , respectively.

A Bayesian approach using Markov chain Monte Carlo (MCMC) methods (Korsgaard et al. 2003) was used for the genetic analysis of the different $\mathrm{CM}$ traits. In matrix notation the general linear model is:

$\lambda=\mathrm{X} \beta+\mathrm{X}_{h}+\mathrm{Z}_{s} \mathrm{~s}+\varepsilon$ where

$\lambda$ is unobserved liabilities to $\mathrm{CM}$

$\beta \quad$ is vector of fixed effects

$\mathrm{h} \quad$ is vector of herd-3-year of calving effects

$\mathrm{s} \quad$ is vector of sire genetic effects

$\varepsilon \quad$ is vector of residual effects

$\mathbf{X}, \mathbf{X}_{\mathrm{h}}$ and $\mathbf{Z}_{\mathrm{s}}$ are incidence matrices that link appropriate effects in vectors $\beta, \mathrm{h}$, and $\mathrm{s}$ to the liabilities to CM.

The fixed effects in $\beta$ were age at first calving and calving year-calving season. Age at first calving (in months) had 8 classes in the first lactation. The calving season in Finland is divided into 3 seasons of four months starting in October and the calving year-calving season had 36 classes. The data from 1992-2002 was divided into four 3-year periods (1992-1994, 1995-1997, 1998-2000, 2000-2002) in order to make classes for the herd3 -year period of calving effect. There were 4355 herds and 14384 herd-3-year of calving periods. The herd-3-year effect was treated as random in order to avoid the extreme category problem (ECP). ECP arises when there is small number of records per class and the prevalence of CM is either high or low giving rise to the possibility that all observations fall in the same category, as either " 1 " or " 0 ". When this occurs, the maximum likelihood estimates of such effects, when treated as fixed, are not finite. Treating herd effects as random with 


\section{AGRICULTURAL AND FOOD SCIENCE}

Negussie, E. et al. Genetic analysis of clinical mastitis

null mean can remove biases in inferences about variance components (Moreno et al. 1997).

\section{Prior distributions}

Independent uniform prior, U(-99,99) was assigned to each of the elements of $\beta$. A multivariate normal prior distribution was assigned to the herd-3-year effect, $\mathbf{h} \sim \mathrm{N}\left(0, \sigma_{\mathrm{h}}{ }^{2} \mathbf{I}\right)$ and to the sire additive genetic effects, $\mathbf{s} \sim \mathrm{N}\left(0, \sigma_{\mathrm{g}}{ }^{2} \mathbf{A}\right)$. Here $\sigma_{\mathrm{h}}{ }^{2}$ and $\sigma_{\mathrm{g}}{ }^{2}$ are variances of herd-3-year and sire effects, respectively, and $\mathbf{A}$ is the matrix of additive relationship between sires of order 1226. Inverted chi-square prior distributions were assumed for $\sigma_{\mathrm{h}}^{2}$ and $\sigma_{\mathrm{g}}^{2}$.

\section{Convergence diagnostics}

The Gibbs sampler was run as a single chain. Length of burn-in and of sampling period, and a measure of mixing rate were obtained following Raftery and Lewis (1992). The effective number of iterates was determined by the initial positive sequence estimation (Geyer 1992). Based on the above-mentioned diagnostics and on visual inspection of trace plots, a chain of 50000 iterations was run, after a burn-in of 5000 rounds. All post burn-in samples were kept for inference about posterior distributions.

\section{Linear model analysis}

Inferences regarding estimates of covariance components from the univariate Bayesian analyses were compared with those obtained from the corresponding REML analyses. In the linear model, the binary nature of CM traits is ignored. The general structure of the model is as given above except that here $\lambda$ is a vector of observations of CM (i.e. " 0 " or " 1 ") on the observable scale. Variance components were estimated using the AI-REML procedure in the DMU package (Madsen and Jensen 2002).

\section{Sire evaluation}

Correlations between estimated breeding values (EBVs) of the different CM traits were used to assess the effect of CM trait definition on sire evaluation. Using Data II, six different univariate BLUP analyses were made to estimate breeding values for each of the six CM traits defined over the different risk periods. In addition, a multi-trait BLUP analysis was made fitting a multi-trait model for CM2, CM4, and CM5 traits and a multi-trait index was calculated by giving equal weight for all traits. A mixed-linear model was used for estimation of breeding values and effects included in the model were the same as those used for the estimation of covariance components. Mixed model equations were solved by preconditioned conjugate gradient (PCG) method with iteration on data technique using the MIX99 software (Strandén and Lidauer 1999).

\section{Results and discussion}

\section{Genetic parameters}

\section{Heritability}

Heritability estimates using the linear model for Data I and Data II ranged from 0.005 to 0.024 and from 0.005 to 0.029 (Table 2), respectively, depending on the stages of lactation or the risk period defined. In both Data I and Data II, the lowest heritability estimates were for CM4 and CM5, reflecting the low incidence of $\mathrm{CM}$ during this period. The highest estimates of heritablity were for CM6 with estimates of 0.024 and 0.029 from Data I and II, respectively. Heritability estimates for CM 1, CM2 and CM3 were all about the same i.e., 0.023 from Data I, and 0.024 from Data II, respectively. This agrees with results using the linear model analysis on records from the Danish Red cows, which involved different risk periods (Lund et al. 1999). They reported a slightly higher heritability estimate for the period from 10 days before to 300 days after calving compared to other risk periods (Lund et al. 1999). On the underlying liability scale, however, they found the highest heritability for the period from 10 days before to 50 days after calving. It seems that most of the genetic variation in $\mathrm{CM}$ is in early lactation.

When heritability estimates of CM traits from 


\section{AGRICULTURAL AND FOOD SCIENCE}

Vol. 16 (2007): 115-123

Table 2. Linear model estimates of variance components, sire $\left(\sigma_{s}^{2}\right)$, residual $\left(\sigma_{e}^{2}\right)$ variance and heritabilities $\left(h^{2}\right)$ of clinical mastitis (CM) traits in first lactation Finnish Ayrshire from Data $\mathrm{I}^{1}$ and Data $\mathrm{II}^{2}$. Subscripts are standard errors for the estimates.

\begin{tabular}{|c|c|c|c|c|c|c|}
\hline \multirow{2}{*}{$\begin{array}{l}\text { Traits } \\
\text { (Days after } \\
\text { calving) }\end{array}$} & \multicolumn{3}{|c|}{ Data I } & \multicolumn{3}{|c|}{ Data II } \\
\hline & $\begin{array}{c}\sigma_{\mathrm{s}}^{2} \\
(\mathrm{x} 100)\end{array}$ & $\begin{array}{c}\sigma_{\mathrm{e}}^{2} \\
(\mathrm{x} 100)\end{array}$ & $\mathrm{h}^{2}$ & $\begin{array}{c}\sigma_{\mathrm{s}}^{2} \\
(\mathrm{x} 100)\end{array}$ & $\begin{array}{c}\sigma_{\mathrm{e}}^{2} \\
(\mathrm{x} 100)\end{array}$ & $\mathrm{h}^{2}$ \\
\hline CM1 (-7-150) & $0.042_{0.005}$ & $7.104_{0.031}$ & $0.023_{0.004}$ & $0.046_{0.005}$ & $7.539_{0.036}$ & $0.024_{(0.004)}$ \\
\hline CM2 (-30-30) & $0.031_{0.004}$ & $5.452_{0.024}$ & $0.022_{0.005}$ & $0.031_{0.004}$ & $5.453_{0.026}$ & $0.023_{(0.005)}$ \\
\hline CM3 (-30-150) & $0.043_{0.005}$ & $7.192_{0.032}$ & $0.023_{0.004}$ & $0.047_{0.006}$ & $7.626_{0.036}$ & $0.024_{(0.004)}$ \\
\hline CM4 (31-150) & $0.003_{0.008}$ & $2.385_{0.010}$ & $0.005_{0.005}$ & $0.005_{0.001}$ & $2.828_{0.013}$ & $0.007_{(0.005)}$ \\
\hline CM5 (151-300) & $0.005_{0.001}$ & $2.388_{0.010}$ & $0.007_{0.007}$ & $0.009_{0.002}$ & $4.024_{0.018}$ & $0.009_{(0.006)}$ \\
\hline CM6 (-30-300) & $0.054_{0.007}$ & $8.651_{0.039}$ & $0.024_{0.005}$ & $0.077_{0.008}$ & $10.292_{0.047}$ & $0.029_{(0.004)}$ \\
\hline
\end{tabular}

${ }^{1}$ Data I: Records of cows culled before the end of the risk period were not included.

${ }^{2}$ Data II: Records of cows culled due to mastitis before the end of the risk period were included.

Data I and Data II were compared, estimates for CM1, CM2, CM3 from Data II were 5\% higher than those from Data I. These were CM traits, which were defined over the risk periods covering the early lactation stages. However, for CM traits, which were defined over the later lactation stages, the difference in heritability estimates between the two data sets was higher. Generally, estimates of heritabilities from Data II were 14 to $25 \%$ higher than those from Data I (Table 2). This is not unexpected because in the late period, the intervals for $\mathrm{CM}$ traits were longer and most cows are culled from the herd due to mastitis and other reasons. This in effect has increased the amount of available information on $\mathrm{CM}$ and hence higher heritabilities. With the inclusion of information about culled cows, increased sire variance and higher heritability of CM has also been reported for first lactation Norwegian dairy cattle (Heringstad et al. 2001a). In analyses of dairy cattle field records, either including or excluding records of culled cows may in general cause data sampling biases, is properly discussed by Heringstad et al. (2003a) and Heringstad et al. (2003b).

Results from the threshold model analyses are in Figure 1 and Table 3. In Figure 1, plots of the marginal posterior densities of heritability of liability to CM traits from Data II are presented. Two groups in the heritability of liability to $\mathrm{CM}$ for the different risk periods were observed except for CM1, CM3 and CM6 (Table 3). CM1 is a trait that is currently used in the national genetic evaluation of CM in Finland. The trait CM2 is a slight extension of CM1 and was designed to include CM information starting from one month before calving instead of 7 days before calving, which is the case of CM1. On the other hand, CM6 was a trait defined to include information on $\mathrm{CM}$ covering the whole lactation starting from one month before calving to culling, 300 days after calving or second calving which ever occurred first. The result in Figure 1 on comparing these three CM traits (CM1, CM3 and CM6) shows no differences. Plots of the marginal posterior density of heritabilities of liability to $\mathrm{CM}$ were also somewhat similar. The reasons for this could be that the longer interval, i.e. CM6, ignored repeated cases of $\mathrm{CM}$ and resulted in a reduction of information on $\mathrm{CM}$. Moreover, the genetic correlations between these traits were very high $(\sim 0.98)$. As a consequence, the longer interval did not show any major improvement over CM1 and CM3, which were defined over comparatively shorter intervals. Similarly, CM3, which was extended to include incidences of $\mathrm{CM}$ recorded much earlier before calving, was also not superior to a relatively shorter period of CM2. This could be an indication that by going much earlier before lactation there was not much $\mathrm{CM}$ 


\section{AGRICULTURAL AND FOOD SCIENCE}

Negussie, E. et al. Genetic analysis of clinical mastitis

Table 3. Posterior means of sire variance $\left(\sigma_{\mathrm{s}}^{2}\right)$ and heritability $\left(\mathrm{h}^{2}\right)$ of liability to clinical mastitis (CM) traits from univariate threshold model analyses in first lactation Finnish Ayrshire from Data $\mathrm{I}^{1}$ and Data $\mathrm{II}^{2}$. Subscripts are posterior standard deviations for the estimates.

\begin{tabular}{lccccc}
\hline Traits & \multicolumn{3}{c}{ Data I } & & \multicolumn{2}{c}{ Data II } \\
\cline { 2 - 5 } \cline { 5 - 6 } (Days after calving) & $\begin{array}{c}\sigma_{\mathrm{s}}^{2} \\
(\mathrm{x} 100)\end{array}$ & $\mathrm{h}^{2}$ & & $\begin{array}{c}\sigma_{\mathrm{s}}^{2} \\
(\mathrm{x} 100)\end{array}$ & $\mathrm{h}^{2}$ \\
\hline CM1 (-7-150) & $1.629_{0.27}$ & $0.064_{0.011}$ & & $1.849_{0.26}$ & $0.072_{0.010}$ \\
CM2 (-30-30) & $1.957_{0.32}$ & $0.076_{0.012}$ & & $2.142_{0.32}$ & $0.083_{0.012}$ \\
CM3 (-30-150) & $1.674_{0.27}$ & $0.065_{0.011}$ & & $1.881_{0.26}$ & $0.073_{0.010}$ \\
CM4 (31-150) & $0.863_{0.33}$ & $0.034_{0.013}$ & & $1.108_{0.32}$ & $0.043_{0.012}$ \\
CM5 (151-300) & $1.194_{0.35}$ & $0.042_{0.013}$ & & $1.071_{0.25}$ & $0.047_{0.010}$ \\
CM6 (-30-300) & $1.583_{0.24}$ & $0.062_{0.010}$ & & $1.867_{0.23}$ & $0.073_{0.010}$ \\
\hline
\end{tabular}

${ }^{1}$ Data I: Records of cows culled before the end of the risk period were not included.

${ }^{2}$ Data II: Records of cows culled due to mastitis before the end of the risk period were included.

information to be captured in Finnish Ayrshire, or the two are just measures of the same trait. This agrees with Heringstad et al. (1997) who reported that although inclusion of CM records before calving resulted in higher heritability estimates, there was no difference between the periods starting 10 , 20 , or 30 days prior to calving.

In the threshold model analysis, the inclusion of information from culled cows resulted in higher heritability of liability to all CM traits compared to the corresponding estimates from Data I (Table 3). The increase was quite constant and ranged from $11 \%$ for CM 5 to $17 \%$ for CM6. This agrees with the results from the linear model analysis. However, among all the CM traits, the heritability of liability to CM was highest for CM2 (-30 to 30) with estimates of 0.076 and 0.083 from Data I and II, respectively. This is despite the lower incidence of CM in this period compared to longer intervals and indicates that estimates on the underlying scale are not frequency dependant.

The higher estimates of heritability for CM2 (-30 to 30$)$ indicate that most genetic variation is found in the early part of the lactation period (Fig 1 and Table 3 ). This could be due to the fact that about 50 to $60 \%$ of the incidences of $\mathrm{CM}$ in Finnish Ayrshire occur during the early period of lactation going from 30 days before calving to 30 days after calving (Koivula et al. 2005). The high heritability for this short interval compared to heritabilities of the longer intervals may also indicate that incidences of $\mathrm{CM}$ in the beginning of lactation, when the animals are facing high physiological demands, are related to the cow's genetic resistance to CM (Lund et al. 1999). This also suggests that there is more variation between sires during this period, and CM2 can be taken as

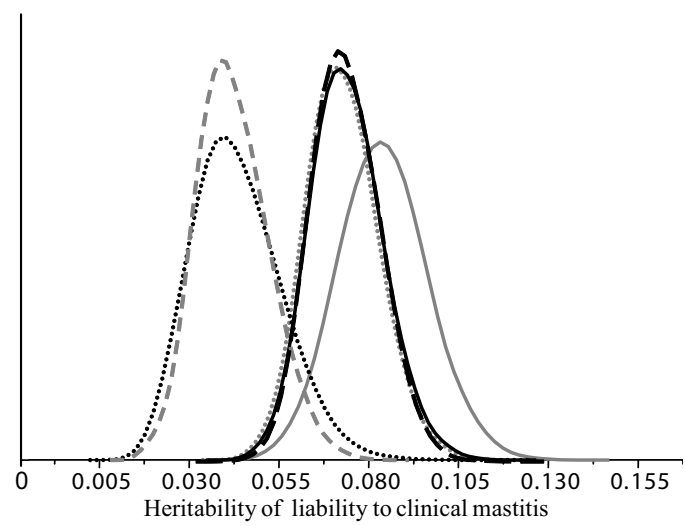

Fig. 1. Posterior distribution of heritability $\left[h^{2}=4 \sigma_{s}^{2} /\left(\sigma_{s}^{2}\right.\right.$ $+1)]$ of liability to clinical mastitis (CM) traits from Data II: CM1 (-7 to 150 days, black line), CM2 (-30 to 30 days, thick gray line), CM3 (-30 to 150 days, dotted gray line), CM4 (31 to 150 days, dotted black line), CM5 (150 to 300 days, broken gray lines) and CM6 (-30 to 300 days, broken black lines). 
Vol. 16 (2007): 115-123

a suitable measure of $\mathrm{CM}$ for sire evaluation. In addition, since economic losses due to mastitis are higher during the beginning of lactation, selection of sires based on low mastitis probabilities during the early period of lactation would be rational. On the other hand, the lower heritability estimates for the longer risk periods (such as CM6) compared to $\mathrm{CM} 2$ suggests loss of genetic information on $\mathrm{CM}$ when multiple cases of $\mathrm{CM}$ are ignored.

\section{Genetic correlation among CM traits}

Genetic correlations between CM traits were slightly higher for Data II than for Data I (Table 4). Estimates from Data I range from 0.42 to 0.99 while those from Data II range from 0.61 to 0.99 (Table 4). Inclusion of information on culled cows in Data II resulted in better data capturing more genetic information on CM. Svendsen and Heringstad (2006) recently reported a genetic correlation of 0.44 to 0.90 between three CM traits defined for the first lactation Norwegian Red cattle. This is in line with the results of the current study. However, the slightly higher correlation from our study is due to some of the overlapping traits included in the analyses. So far, there are only few studies that have considered the correlation between CM traits defined for the different risk periods. Using a linear sire model, Lund et al. (1999) found that the genetic correlation between clinical mastitis in early lactation (-10 to 50 days after first calving) versus other periods ranged from 0.68 to 0.89 in Danish Red cows. In contrast, Emanuelson et al. (1988) found a negative genetic correlation between the periods of -10 to 150 days from parturition and 150 days after calving in Swedish Red cattle. Heringstad et al. (2003b) found moderate to high genetic correlations using a longitudinal threshold model up to 270 days in milk for first-lactation Norwegian Red cattle. Generally, the moderate to high genetic correlations between CM traits found in our study suggest that susceptibility to $\mathrm{CM}$ varies during lactation, which is probably due to different genes operating at different parts of the lactation.

\section{Effect of clinical mastitis trait definition on sire evaluation}

Correlations between breeding values for CM traits defined for the different risk periods are in Table 5. Overall, the result shows that correlations between sire evaluations range from medium to high (0.33 to 0.99). Compared to all other CM trait evaluations the multi-trait index calculated by combining CM information form CM2, CM4 and CM5 had the highest correlations with all the other CM trait evaluations. Therefore, our result suggests that a multi-trait index is more suitable for CM sire evaluation than a single-trait analysis, which by ignoring repeated cases of $\mathrm{CM}$ reduces the available genetic information on CM. In addition, such evaluation apart from making effective use of available information enables to address

Table 4. Estimates of genetic correlations and standard errors between clinical mastitis (CM) traits defined over the different risk periods in first lactation Finnish Ayrshire from Data $\mathrm{I}^{1}$ (above diagonal) and Data $\mathrm{II}^{2}$ (below diagonal). Subscripts are standard errors for the estimates.

\begin{tabular}{lcccccc}
\hline $\begin{array}{l}\text { Traits } \\
\text { (Days after calving) }\end{array}$ & $\begin{array}{c}\text { CM1 } \\
(-7-150)\end{array}$ & $\begin{array}{c}\text { CM2 } \\
(-30-30)\end{array}$ & $\begin{array}{c}\text { CM3 } \\
(-30-150)\end{array}$ & $\begin{array}{c}\text { CM4 } \\
(31-150)\end{array}$ & $\begin{array}{c}\text { CM5 } \\
(151-300)\end{array}$ & $\begin{array}{c}\text { CM6 } \\
(-30-300)\end{array}$ \\
\hline CM1 (-7 to 150) & & $0.97_{0.011}$ & $0.99_{0.001}$ & $0.95_{0.065}$ & $0.57_{0.116}$ & $0.98_{0.006}$ \\
CM2 (-30 to 30) & $0.97_{0.014}$ & & $0.98_{0.009}$ & $0.87_{0.126}$ & $0.42_{0.128}$ & $0.93_{0.020}$ \\
CM3 (-30 to 150) & $0.99_{0.004}$ & $0.97_{0.012}$ & & $0.94_{0.072}$ & $0.57_{0.115}$ & $0.98_{0.006}$ \\
CM4 (31 to 150) & $0.96_{0.051}$ & $0.84_{0.120}$ & $0.94_{0.061}$ & & $0.91_{0.126}$ & $0.99_{0.066}$ \\
CM5 (151 to 300) & $0.75_{0.093}$ & $0.61_{0.114}$ & $0.75_{0.093}$ & $0.94_{0.088}$ & $0.68_{0.085}$ \\
CM6 (-30 to 300) & $0.98_{0.008}$ & $0.93_{0.024}$ & $0.98_{0.008}$ & $0.99_{0.057}$ & $0.83_{0.058}$ & \\
\hline
\end{tabular}

${ }^{1}$ Data I: Records of cows culled before the end of the risk period were not included.

${ }^{2}$ Data II: Records of cows culled due to mastitis before the end of the risk period were included. 


\section{AGRICULTURAL AND FOOD SCIENCE}

Negussie, E. et al. Genetic analysis of clinical mastitis

Table 5. Rank (Spearman, above diagonal) and product moment (Pearson, below diagonal) correlations between estimated breeding values from the different clinical mastitis (CM) traits and a multi-trait index calculated from a multitrait linear model analyses of three CM traits (CM2, CM4 and CM5) for sires with at least 50 daughters.

\begin{tabular}{lccccccc}
\hline $\begin{array}{l}\text { Traits } \\
\text { (Days from calving) }\end{array}$ & $\begin{array}{c}\text { CM1 } \\
(-7-150)\end{array}$ & $\begin{array}{c}\text { CM2 } \\
(-30-30)\end{array}$ & $\begin{array}{c}\text { CM3 } \\
(-30-150)\end{array}$ & $\begin{array}{c}\text { CM4 } \\
(31-150)\end{array}$ & $\begin{array}{c}\text { CM5 } \\
(151-300)\end{array}$ & $\begin{array}{c}\text { CM6 } \\
(-30-300)\end{array}$ & $\begin{array}{c}\text { CM245 } \\
\text { (MTindex) }\end{array}$ \\
\hline CM1 (-7 to 150) & & 0.89 & 0.99 & 0.66 & 0.27 & 0.95 & 0.96 \\
CM2 (-30 to 30) & 0.90 & & 0.90 & 0.33 & 0.17 & 0.85 & 0.90 \\
CM3 (-30 to 150) & 0.99 & 0.90 & & 0.65 & 0.26 & 0.96 & 0.96 \\
CM4 (31 to 150) & 0.68 & 0.34 & 0.68 & & 0.34 & 0.66 & 0.62 \\
CM5 (151 to 300) & 0.26 & 0.16 & 0.26 & 0.33 & & 0.45 & 0.42 \\
CM6 (-30 to 300) & 0.96 & 0.86 & 0.96 & 0.68 & 0.46 & & 0.97 \\
CM245 (MTindex) & 0.96 & 0.91 & 0.97 & 0.63 & 0.43 & 0.98 & \\
\hline
\end{tabular}

the diversity of CM occurring at different stages of lactation due to different pathogens or other causative agents.

\section{Conclusions}

Including records of culled cows resulted in increased sire variance, heritability and slightly increased genetic correlations between the different $\mathrm{CM}$ traits, implying better data capturing more genetic information on CM. Results of the threshold analyses showed that the posterior mean heritability of liability to $\mathrm{CM}$ was highest for CM2 (-30 to 30 days after calving) and followed by CM6 (-30 to 300d), CM3 (-30 to $150 \mathrm{~d})$ and CM1 (-7 to 150$)$ with estimates of 0.083 , $0.073,0.073$ and 0.072 , respectively. The high heritability estimate for CM2 trait (-30 to 30 days after calving) indicates that most genetic information is in early lactation. Genetic correlations between CM traits defined over the different risk periods were less than one, implying that mastitis cannot be regarded as the same trait during lactation. Therefore, a multivariate model treating mastitis in different stages of lactation as different traits is appropriate for accurate genetic evaluation.

Acknowledgements. The authors are grateful to the Finnish Animal Breeding Association (Faba) for providing all the necessary information. The project has received funding from the Finnish Ministry of Agriculture and Forestry.

\section{References}

Chang, Y.M., Gianola, D., Heringstad, B. \& Klemetsdal, G. 2004. Effects of trait definition on genetic parameter estimates and sire evaluation for clinical mastitis with threshold models. Animal Science 79: 355-363.

Dempster, E.R. and Lerner, I.M. 1950. Heritability of threshold characters. Genetics 35: 212-236.

Emanuelson, U., Danell, B., \& Philipsson, J. 1988. Genetic parameters for clinical mastitis, somatic cell counts, and milk production estimated by multiple-trait restricted maximum likelihood. Journal of Dairy Science 71: 467-476.

Falconer, D.S. \& Mackay, T.F.C. 1996. Introduction to quantitative genetics, $4^{\text {th }}$ Edition. Longman, New York, $464 \mathrm{p}$. ISBN 0582-24302-52.

Geyer, C.J. 1992. Practical Markov Chain Monte Carlo. Statistical Science 7: 473-511.

Gianola, D. 1982. Theory and analysis of threshold characters. Journal of Animal Science 54: 1079-1096.

Heringstad, B., Karlsen, A., Klemetsdal, G., \& Ruane, J. 1997. Preliminary results from the genetic analysis of clinical mastitis data. Interbull Bulletin No. 15: 45-49.

Heringstad, B., Klemetsdal, G. and Ruane, J. 2001a. Variance components of clinical mastitis in dairy cattle - effects of trait definition and culling. Livestock Production Science 67: 265-272.

Heringstad, B., Rekaya, R., Gianola, D., Klemetsdal, G. \& Weigel, K.A. 2001b. Bayesian analysis of liability to clinical mastitis in Norwegian cattle with a threshold model: Effects of data sampling method and model specification. Journal of Dairy Science 84: 2337-2346.

Heringstad, B., Rekaya, R., Gianola, D., Klemetsdal, G. \& Weigel, K.A. 2003a. Bivariate analysis of liability to clinical mastitis and to culling in first lactation cows. Journal of Dairy Science 86: 653-660.

Heringstad, B, Chang, Y.M., Gianola, D., \& Klemetsdal, G. 2003b. Genetic analysis of longitudinal trajectory of clinical mastitis in first-lactation Norwegian Red cattle. Journal of Dairy Science 86: 2676-2683.

Im, S., Fernando, R.L. \& Gianola, D. 1989. Likelihood inferences in animal breeding under selection - a missingdata theory view point. Genetics Selection and Evolution 21: 399-414. 
Vol. 16 (2007): 115-123

Koenen, E., Berglund, B., Philipsson, J., \& Groen, A. 1994. Genetic parameters of fertility disorders and mastitis in the Swedish Friesian breed. Acta Agriculturae Scandinavica Section A 44: 202-207.

Koivula, M., Mäntysaari, E.A., Negussie, E. \& Serenius, T. 2005. Genetic and phenotypic relationships among milk yield and somatic cell count before and after clinical mastitis. Journal of Dairy Science 88: 827-833.

Korsgaard, I.R., Lund, M.S., Sorensen, D., Gianola, D., Madsen, P. \& Jensen, J. 2003. Multivariate Bayesian analysis of Gaussian, right censored Gaussian, ordered categorical and binary traits using Gibbs sampling. Genetics Selection Evolution 35: 159-183.

Little, R.J.A. \& Rubin, D.B. 1987. Statistical Analysis with Missing Data. Wiley, New York.

Lund, M.S., Jensen, J. \& Peterson, P.H. 1999. Estimation of genetic and phenotypic parameters for clinical mastitis, somatic cell production deviance, and protein yield in dairy cattle using Gibbs sampling. Journal of Dairy Science 82: 1045-1051.

Madsen, P. \& Jensen, J. 2002. A User's Guide to DMU. A package for analyzing multivariate mixed models. Version 6, release 4. Danish Institute of Agricultural
Sciences, Denmark.

Moreno, C., Sorensen, D., Garcia-Cortes, L.A., Varona, L \& Altarriba, J. 1997. On biased inferences about variance components in the binary threshold model. Genetics Selection Evolution 29: 145-160.

Negussie, E., Koivula, M. \& Mäntysaari, E.A. 2006. Genetic parameters and single- versus multi-trait evaluation of udder health traits. Acta Agriculturae Scand Section A 56: 73-82.

Pösö, J. \& Mäntysaari, E.A. 1996. Relationships between clinical mastitis, somatic cell score, and production for the first three lactations of Finnish Ayrshire. Journal of Dairy Science 79: 1284-1291.

Raftery, A.L. \& Lewis, S. 1992. How many iterations in the Gibbs sampler? Pages 763-774 in Bayesian Statistics 4. J.M. Bernando, J.O. Berger, A.P. Dawid, and A.F.M. Smith ed. Oxford University Press, Oxford UK.

Stranden, I., \& Lidauer, M., 1999. Solving large mixed linear models using preconditioned conjugate gradient iteration. Journal of Dairy Science 75: 2017-2022.

Svendsen, M. \& Heringstad, B. 2006. New genetic evaluation for clinical mastitis in multiparous Norwegian Red cows. Interbull Bulletin No. 35: 8-11.

\title{
SELOSTUS
}

\section{Kliinisen utaretulehduksen geneettinen analyysi lypsykauden eri vaiheissa suomalaisella ayrshirelypsykarjalla}

\author{
Enyew Negussie, Ismo Strandén ja Esa A. Mäntysaari \\ MTT Biotekniikka- ja elintarviketutkimus
}

Tutkimuksessa arvioitiin ensi kertaa poikivien ayrshirerotuisten lypsylehmien kliinisen utaretulehduksen (CM) varianssikomponentteja lineaarimallilla ja kynnysominaisuuden mallilla. Tarkastellut CM-ominaisuudet saatiin jakamalla ensimmäinen lypsykausi kuuteen eri ajanjaksoon eli riskiperiodiin, jotka määritettiin poikimisesta alkaen seuraavasti: CM1 (-7-150 päivää poikimisesta), CM2 (-30-30 pv), CM3 (-30-150 pv), CM4 (31-150 pv), CM5 (150-300 pv) ja CM6 (-30-300 pv). Saatuja tietoja tarkasteltiin kahdessa aineistossa: Data I:stä oli poistettu ensimmäisellä lypsykaudella teurastettujen lehmien tiedot, Data II:ssa myös nuo tiedot olivat mukana. Kun ensimmäisellä lypsykaudella teuras- tettujen lehmien tiedot huomioitiin, isävarianssi ja heritabiliteetti olivat suurempia. Arvioitu heritabiliteetti oli lineaarimalleilla hiukan sitä korkeampi mitä pidempi oli CM-ominaisuuden ajanjakso, joten pidempi ajanjakso näyttää häiritsevän geneettisen vaihtelun arviointia. Kun $\mathrm{CM}$ analysoitiin kynnysarvo-ominaisuutena, heritabiliteetti oli korkein CM2-kaudella $\left(\mathrm{h}^{2}=0.083\right)$. Suurin osa geneettisestä vaihtelusta tapahtuu siis laktaation alussa. Isämallin jalostusarvosteluissa koko lypsykauden indeksillä (CM2 + CM4 + CM5) oli suurempi korrelaatio yhden ominaisuuden CM-arvosteluihin kuin yksittäisillä $\mathrm{CM}$-arvosteluilla. Isämallissa kannattaa siis jakaa CM ajanjaksojen mukaan eri ominaisuuksiksi. 